\title{
KOMUNIKASI DAKWAH KOLABORATIF PEMERINTAH DESA MELALUI KEBIJAKAN PUBLIK
}

\author{
Miftahul Huda ${ }^{1}$, Muhammad Ulin Nuha ${ }^{2}$, Dewi Mashfufah ${ }^{3}$ \\ Universitas Selamat Sri Kendal, Universitas Islam Negeri Sunan Kalijaga, \\ Universitas Islam Negeri Walisongo Semarang \\ E-mail:mashudadm@gmail.com,nuha0623@gmail.com, \\ kayyesadewi@gmail.com
}

\begin{abstract}
Abstrak
Desa Margoyoso Jepara merupakan desa yang memiliki problematika sosial keagamaan sebagai bagian dari dampak negatif perkembangan zaman. Dengan kondisi tersebut, Pemerintah Desa melakukan komunikasi dakwah kolaboratif dalam mengatasi problematika tersebut. Jenis Penelitian ini adalah kualitatif dengan metode penelitian lapangan. Dalam penelitian ini, teknik pengumpulan data melalui wawancara, observasi, dan dokumentasi. Teknik analisis data yang digunakan berupa induktif dan deskriptif naratif. Hasil penelitian ini menjelaskan bahwa dakwah kolaboratif di Pemerintahan Desa Margoyoso dipengaruhi adanya sistem otonomi desa, dimana Pemerintah Desa dapat mengelola dan mengatur wilayah pemerintahannya sendiri sesuai dengan khas dan coraknya masing-masing. Munculnya kebijakan dakwah kolaboratif dilatarbelakangi oleh permasalahan sosial dan politik keagamaan. Pesan Komunikasi dakwah yang berupa gerakan shalat subuh berjamaah, mematikan televisi setelah maghrib, ayo mengaji, dan wajib madrasah diniyah dibentuk melalui proses musyawarah oleh Pemerintah Desa, tokoh masyarakat, tokoh agama, organisasi sosial keagamaan, dan stakeholder terkait. Kebijakan dakwah kolaboratif memiliki manfaat sebagai sarana untuk mempererat silaturrahmi dengan warga, sarana sosialisasi dan informasi Desa, serta sarana untuk meningkatkan kualitas keagamaan dan pendidikan masyarakat.
\end{abstract}

Kata kunci: Komunikasi, Dakwah Kolaboratif, Pemerintah Desa, Kebijakan Publik

\begin{abstract}
Margoyoso Jepara village is a village that has socio-religious problems as part of the negative impact of the times. Under these conditions, the Village Government carried out collaborative da'wah communication in overcoming these problems. This type of research is qualitative with field research methods. In this study, data collection techniques through interviews, observation, and documentation. Data analysis techniques used in the form of inductive and descriptive narrative. The results of this study explain that collaborative da'wah in the Margoyoso Village Government is influenced by the existence of a village autonomy system, where the Village Government can manage and regulate its own government area according to the characteristics and styles of each. The emergence of collaborative da'wah policies is motivated by social and political religious problems. The message of
\end{abstract}


Da'wah communication in the form of congregational dawn prayers, turning off the television after sunset, let's recite the Koran, and compulsory madrasah diniyah was formed through a deliberation process by the Village Government, community leaders, religious leaders, socio-religious organizations, and related stakeholders. Collaborative da'wah policy has benefits as a means to strengthen friendship with residents, a means of socialization and village information, as well as a means to improve the quality of religion and community education.

Keywords: Communication, Collaborative Da'wah, Village Government, Public Policy

\section{PENDAHULUAN}

Rasulullah merupakan manusia pilihan Allah SWT yang diutus untuk memberikan keteladanan dalam segala aspek kehidupan. Salah satu ajaran yang diteladankan Rasulullah kepada umatnya adalah Berdakwah. Dalam melaksanakan kegiatan dakwah, Rasulullah menggunakan berbagai macam strategi dan pendekatan. Pada mulanya, pendekatan yang digunakan adalah personal aproach atau pendekatan individu dengan mengajak keluarga, kerabat, dan sahabat untuk berislam. Setelah itu, Rasulullah kemudian menggunakan pendekatan terangterangan atau terbuka kepada masyarakat luas untuk berislam. ${ }^{1}$

Kegiatan dakwah yang telah dipraktikkan oleh Rasulullah kemudian dilanjutkan oleh para sahabat hingga umatnya sekarang di berbagai penjuru dunia, termasuk di Indonesia yang terkenal dengan Islam Nusantara. kegiatan dakwah di Indonesia pada umumnya dipraktikkan dengan menggunakan pendekatan kultural seperti pengajian, majlis ilmu, kesenian, kebudayaan, dan lain sebagainya. Tetapi seiring dengan perkembangan zaman, dakwah memiliki berbagai macam tantangan yang dipengaruhi adanya perubahan sosial yang terjadi seperti perkembangan dibidang teknologi informasi dan globalisasi yang dampak negatifnya dapat menyebabkan adanya peningkatan kemaksiatan baik secara kualitas maupun kuantitas, serta degradasi moral, kenakalan remaja, kriminalitas, pornografi dan pornoaksi, dan lain sebagainya.

Adanya tantangan dakwah tersebut mengindikasikan bahwa kegiatan dakwah melalui metode lisan atau ceramah dan tulisan dipandang belum mampu

\footnotetext{
${ }^{1}$ Khatib Pahlawan Kayo, Manajemen Dakwah, (Jakarta: Amzah, 2007), 6.
} 
menjadi solusi yang efektif, sehingga pendekatan kultural dipandang perlu diperkuat dengan pendekatan struktural sebagaimana yang dilaksanakan di berbagai daerah. Dakwah struktural merupakan langkah pendekatan dakwah yang dilakukan secara legal formal melalui struktur atau kelembagaan. Lahirnya dakwah struktural dipegaruhi dari penafsiran undang-undang otonomi daerah yang menjelaskan bahwa daerah memiliki wewenang, hak, dan kewajiban dalam mengelola dan mengatur wilayahnya sesuai dengan perundang-undangan yang berlaku, serta pemerintah desa mempunyai kewenangan dalam pembinaan kemasyarakatan, pembangunan desa, pembinaan kemasyarakatan, dan pemberdayaan masyarakat.

Implementasi dakwah struktural dapat dilihat misalnya di Kabupaten Bandung yang memilki program dakwah struktual dengan konsep Bandung Agamis. Program tersebut digagas oleh Ridwan Kamil dalam upaya untuk meningkatkan kualitas spiritual masyarakat Bandung. Program Bandung Agamis menelurkan beberapa program kebijakan seperti Gerakan Magrib Mengaji, Gerakan Ayo Bayar Zakat, dan Gerakan Salat Subuh Berjamaah. ${ }^{2}$ Bulukumba yang menjadi daerah pertama di Sulawesi Selatan juga menerapkan kebijakan dakwah struktural melalui program larangan menjual minuman keras, pengelolaan zakat, pakaian muslim dan muslimah, serta regulasi tentang kemampuan untuk membaca dan menulis al Quran bagi siswa dan calon pengantin. ${ }^{3}$

Selain di Bandung dan Bulukumba, Dakwah struktural juga dilaksanakan di Jepara, salah satu kota yang mempunyai basis keagamaan kuat. Jepara memiliki kuantitas lembaga pendidikan yang banyak, seperti madrasah, pondok pesantren, serta pendidikan formal maupun non formal. ${ }^{4}$ Pada tahun 2014, Jepara menjadi kota yang memiliki pondok pesantren terbanyak se Jawa Tengah. ${ }^{5}$ Jepara juga pernah mendapatkan penghargaan dari pemerintah pusat sebagai daerah yang sangat peduli

\footnotetext{
${ }^{2}$ Lihat https://bimasislam.kemenag.go.id/post/berita/ridwan-kamil ini-sejumlah-programke agamaan-islam-di -kota-bandung-.

${ }^{3}$ Amril Maryolo, Formalisasi Syariat Islam di Bulukumba, Tesis Program Studi Islamic Interdisciplinary Studies UIN Sunan Kalijaga Yogyakarta, 2017, 3.

${ }_{4}$ Jumlah lembaga pendidikan baik negeri maupun swasta tingkat SD/MI adalah 789. Tingkat SMP/MTs ada 206, dan tingkat SMA/MA/SMK ada 137. Data tentang jumlah lembaga pendidikan di Jepara melalui Referensi Kementerian Pendidikan dan Kebudayaan. Diakses pada Jumat, 30 Nobember 2018 Pukul 13.58 WIB. Lihat pada http://referensi.data.kemdikbud. go.id/index11. php?kode=032000\&level $=2$.

${ }^{5}$ Kanwil. Departemen Agama Provinsi Jawa Tengah.
} 
dengan pendidikan Islam. ${ }^{6}$ Namun, di Jepara juga terdapat beragam problematika masyarakat. Misalnya angka kenakalan remaja yang tergolong tinggi yaitu 190.194 kasus. ${ }^{7}$

Dakwah kolaboratif merupakan kombinasi antara dakwah kultural dan struktural. Dalam penelitian ini, Pemerintah Desa Margoyoso melaksanakan kolaborasi antara dakwah kultural dan strukturaal dalam membangun desa yaang religius. Alasan peneliti memilih topik penelitian tentang komunikasi dakwah kolaboratif dalam implementasi kebijakan publik karena pemerintah di desa Margoyoso merupakan pemerintah yang melakukan agenda dakwah kolaboratif, kombinasi antara dakwah struktural dan kultural melalui kebijakan publik. Selain itu, perangkat desa Margoyoso juga banyak yang aktif dan menempati posisi strategis di organisasi sosial keagamaan Nahdlatul Ulama yang sangat identik dengan pendekatan kultural. Penelitian ini memiliki keunikan bagaimana dakwah struktural diimplementasikan di pemerintahan desa, yang bersentuhan langsung dengan masyarakat akar rumput yang khas dengan dakwah kultural, sehingga hal tersebut menarik untuk dilihat bagaimana berlangsungnya proses komunikasi dakwah kolaboratif yang terjadi.

\section{METODE PENELITIAN}

Jenis penelitian ini termasuk jenis penelitian kualitatif, dengan menggunakan metode penelitian lapangan. Penelitian ini mengambil lokasi di Kabupaten Jepara dengan membatasi lingkup kajiaanya di desa Margoyoso Kecamatan Kalinyamatan Kabupaten Jepara. Alasan pemilihan desa Margoyoso sebagai objek penelitian adalah karena termasuk desa di kabupaten Jepara yang membuat kebijakan dakwah melalui kebijakan publik.

Sumber data dalam penelitian ini terdiri dari dari sumber data primer dan sekunder. Sumber data yang dimaksud dalam penelitian ini adalah dari mana data yang diperlukan oleh peneliti dapat diperoleh. Menurut Lofland sebagaimana dikutip oleh Lexy J. Moleong, sumber data utama dalam penelitian kualitatif adalah

\footnotetext{
${ }^{6}$ Lihat www.republika.co.id/berita/koran/internasional/-koran/15/ 01/12/ ni1vch1-tujuhkepala -daerah-majukan-pendidikan-islam.

${ }^{7}$ Data ini disampaikan oleh Bupati Jepara pada pembukaan lomba duta pelajar generasi bencana tahun 2017. Lihat http://isknews.com/190-149remaja-jepara-rentan-masalah.
} 
kata-kata dan tindakan, yang lainnya berupa data tambahan seperti dokumen dan lain sebagainya. Data primer merupakan data yang diperoleh langsung dari sumbernya, diamati, dan dicatat untuk pertama kalinya. Sedang 'kan data sekunder merupakan data yang pengumpulannya bukan disuahakan sendiri oleh peneliti. Sumber data primer dalam penelitian ini adalah wawancara dan observasi. Sedangkan sumber data sekundernya adalah dokumentasi. ${ }^{8}$

Dalam Penelitian ini, teknik wawancara yang digunakan adalah semi standar. Artinya, peneliti membuat garis-garis besar pokok pembicaraan, tetapi dalam pelaksanannya mengajukan pertanyaan secara bebas. Peneliti juga menggunakan teknik wawancara tidak standar, dimana peneliti tidak menggunakan pedoman wawancara yang telah tersusun secara sistematis sehingga dapat lebih luas dan terbuka dalam pelaksanannya. Narasumber dalam penelitian ini adalah Kepala Desa, Badan Perwakilan Desa, Sekretaris Desa, tokoh masyarakat, tokoh agama, serta guru di lembaga formal dan non formal. Teknik observasi dalam penelitian ini adalah observasi partisipatif, dimana peneliti mengamati secara langsung dengan tujuan agar dapat merasakan dan memaknai peristiwa dan gejala sosial yang terjadi, serta bagaimana proses komunikasi dakwah kolaboratif pemerintah desa Margoyoso dalam membangun desa yang religius.

Teknik analisis data dalam penelitian ini menggunakan bentuk induktif, artinya peneliti tidak hanya mencari data atau fakta untuk kepentingan pembuktian atau penolakan terhadap teori dan konsep dari komunikasi dakwah, tetapi peneliti berupaya menemukan fakta-fakta yang banyak dan beragam yang kemudian ditelaah sehingga menjadi kesimpulan yang lebih berarti. Penelitian ini juga menggunakan teknik deskriptif naratif yang menurut Miles dan Hubermen dilaksanakan melalui tahap reduksi data, penyajian data, dan penarikan kesimpulan. Peneliti merangkum dan memfokuskan pada hal pokok yang berkaitan dengan komunikasi dakwah Pemerintah Desa Margoyoso yang kemudian disajikan dalam bentuk uraian dan narasi yang berisi tentang jawaban atas rumusan masalah yang telah peneliti tentukan

\footnotetext{
2016), 6 .

${ }^{8}$ Lexy J Moleong, Metodologi Penelitian Kualitatif, (Bandung: PT. Remaja Rosdakarya,
} 


\section{HASIL DAN PEMBAHASAN}

\section{Lahirnya Kebijakan Dakwah Struktural oleh Pemerintah Desa}

Munculnya kebijakan dakwah struktural melalui kebijakan publik di Margoyoso tidak dapat terlepas dari adanya pergeseran tata nilai dalam masyarakat. Tata nilai merupakan aturan pandangan dan anggapan masyarakat yang digunakan sebagai acuan dan pedoman dalam menilai sesuatu dan dalam mengendalikan serta memilih tingkah laku dalam kehidupan sehari-hari. Tata nilai juga dapat diartikan sebagai kumpulan norma yang diakui oleh masyarakat dan digunakan sebagai pedoman dalam menentukan realitas yang ada di sekelilingnya, dan dalam menentukan sikap selanjutnya.

Menurut Tholhah Hasan, ada beberapa faktor yang menyebabkan terjadinya pergeseran tata nilai dalam masyarakat seperti kemajuan ilmu pengetahuan dan teknologi, kemajuan dan pertumbuhan ekonomi, perubahan politik dan peranan kekuasaan pemerintahan, perubahan lingkungan biofisik, dan pengaruh kebudayaan luar. ${ }^{9}$ Faktor-faktor tersebut dapat juga saling berkaitan satu sama lain sehingga memberi kadar pengaruh yang lebih besar, baik pergeseran tata nilai yang bersifat konstruktif maupun yang bersifat destruktif. ${ }^{10}$

Sebenarnya adanya perubahan tata nilai dalam masyarakat tersebut dapat memberikan dampak positif apabila disertai dengan kearifan diri, mampu membedakan antara yang bermanfaat dan tidak, antara yang mengandung maslahah dan mafsadah. Perubahan tata nilai tersebut juga dapat memberikan dampak negatif jika masyarakat mengalami erosi nilai sehingga hal yang tertanam didalamnya menjadi runtuh dan nilai-nilai baru yang menjadi penggantinya belum siap atau belum jelas peranannya. Kondisi tersebut umumnya dialami oleh masyarakat yang sedang mengalami masa transisi seperti halnya masyarakat desa Margoyoso. Pergeseran tata nilai masyarakat disebabkan oleh berbagai problematika yang

${ }^{9}$ Amrullah Amdad (ed), Dakwah Islam dan Transformasi Sosial Budaya, (Yogyakarta: PLP2M, 1985), 60.

${ }^{10}$ Dampak destruktif berupa perombakan struktural tatanan bagian budaya masyarakat yang disebabkan oleh adanya kesenjangan antara kecepatan perkembangan teknologi dan ilmu pengetahuan dengan kecepatan perkembangan bagian tatanan budaya masyarakat lainnya seperti melenturnya solidaritas sosial oleh kelimpahan material yang dibawa oleh teknologi industri. Muhammad Tholhah Hasan, Prospek Islam dalam Menghadapi Tantangan Zaman, (Jakarta: Lantabora Press, 2003), 13. 
timbul menyebabkan pengaruh dalam pola pikir masyarakat. Cara pandang masyarakat terhadap suatu masalah juga dipengaruhi oleh perubahan situasi dan kondisi pada masyarakat serta perkembangan teknologi yang sangat cepat.

Desa Margoyoso secara umum merupakan salah satu desa di Kabupaten Jepara yang memiliki nuansa keagamaan kuat. Hal tersebut dibuktikan dengan banyaknya lembaga pendidikan keagamaan baik formal maupun non formal yang tumbuh dan berkembang seperti sekolah dan Madrasah formal, Madrasah Diniyah, Taman Pendidikan Al Quran, Pondok Pesantren, dan lain sebagainya. Meskipun memiliki nuansa keagamaan yang kuat, desa Margoyoso juga memiliki problematika kemasyarakatan, terutama yang berkaitan dengan degradasi moral, kenakalan remaja, dan berbagai macam bentuk lainnya sebagai akibat dari dampak negatif globalisasi dan perkembangan teknologi informasi yang sangat cepat. Hal tersebut yang menjadikan salah satu motif dari Pemerintah Desa Margoyoso dalam membuat beberapa kebijakan keagamaan.

Di Margoyoso, cerminan dari problematika tersebut misalnya bagaimana anak-anak usia sekolah yang dahulu rutin mengaji al Quran setelah maghrib mulai meninggalkan budaya tersebut dengan menonton televisi, bermain gadget, dan nongkrong di pinggir jalan. Selain itu, pada waktu sore hari yang dahulu digunakan oleh anak-anak untuk belajar di lembaga keagamaan seperti pondok pesantren, Taman Pendidikan Al Quran, dan Madrasah Diniyyah mulai berkurang dikarenakan berbagai macam faktor seperti tidak ada pengawasan dan dorongan dari lingkungan keluarga, pengaruh negatif lingkungan sekitar, dan lain sebagainya.

Perkembangan ilmu pengetahuan dan teknologi secara umum menyebabkan lahirnya perubahan-perubahan dalam berbagai aspek kehidupan manusia, baik dari segi sosial, agama, politik, maupun tradisi masyarakat. Globalisasi dan kemajuan teknologi informasi juga membawa perubahan yang sangat besar dalam berbagai segi tatanan kehidupan manusia seperti cara berpikir, bersikap, dan bertingkah laku. Meskipun kemajuan tersebut mampu membawa perubahan yang besar dan luar biasa, namun kemajuan tersebut dipandang oleh Pemerintah Desa Margoyoso belum mampu menjawab berbagai macam permasalahan kehidupan manusia Secara umum, masalah sosial yang muncul sebagai akibat terjadinya perbedaan yang mencolok antara nilai dalam masyarakat dengan realita yang ada. 
Permasalahan sosial seperti adanya degradasi moral, kenakalan remaja, kriminalitas, dan gejolak politik yang ada suatu wilayah akan mempengaruhi atau memaksa aktor kebijakan untuk meresponnya dengan memasukannya ke dalam agenda pemerintah yang selanjutnya melahirkan kebijakan publik untuk memecahkan masalah-masalah yang bersangkutan. Menurut teori sistem, pembuatan atau lahirnya kebijakan publik tidak dapat terlepas dari pengaruh lingkungan. Tuntutan adanya kebijakan publik biasanya lahir karena adanya pengaruh lingkungan, dan kemudian ditransformasikan ke dalam suatu sistem politik. Adanya dakwah struktural melalui kebijakan publik di Margoyoso tidak dapat terlepas dari adanya pergeseran tata nilai dalam masyarakat. Tata nilai merupakan aturan pandangan dan anggapan masyarakat yang digunakan sebagai acuan dan pedoman dalam menilai sesuatu dan dalam mengendalikan serta memilih tingkah laku dalam kehidupan sehari-hari. Tata nilai juga dapat diartikan sebagai kumpulan norma yang diakui oleh masyarakat dan digunakan sebagai pedoman dalam menentukan realitas yang ada di sekelilingnya, dan dalam menentukan sikap selanjutnya.

Dalam kehidupan sosial masyarakat, Desa Margoyoso dikenal dengan berbagai karakteristik seperti memiliki pergaulan hidup yang saling mengenal antara warga masyarakatnya, memiliki ikatan emosional yang kuat, dan memiliki tingkat religiusitas tinggi. Namun seiring perkembangan zaman, karakteristik sebagaimana tersebut mulai luntur sehingga terdapat berbagai macam permasalahan sosial.

Degradasi moral remaja merupakan salah satu permasalahan sosial yang sering terjadi di Margoyoso. Secara umum, degradasi moral remaja di Margoyoso terjadi karena faktor penyimpangan sosial, perkembangan globalisasi yang tidak seimbang, pengaruh budaya asing, kurangnya pengawasan dan perhatian orang tua, dan rendahnya tingkat pendidikan. Moral remaja dari tahun ketahun mengalami penurunan kualitas atau degradasi dalam berbagai aspek moral seperti tutur kata, cara berpakaian, gaya hidup, dan lain sebagainya.

Faktor ketahanan keluarga menjadi faktor yang mempengaruhi terjadinya degradasi moral remaja di Margoyoso. Sebagai pondasi pertama untuk anak, orang tua sebenarnya memegang peranan penting untuk membentengi anak dari pengaruh 
negatif yang dapat mengikis moral. Beberapa hal yang dikhawatirkan oleh Pemerintah Desa Margoyoso adalah semakin meluasnya penyimpanganpenyimpangan moral seperti minum-minuman keras, narkoba, pornografi, dan lain sebagainya.

Menurut Pemerintah Desa Margoyoso, permasalahan publik di lingkungan Margoyoso sangat komplek sehingga membutuhkan penanganan dari Pemerintah Desa. Berangkat dari permasalahan tersebut, Pemerintah Desa menganggap perlu adanya kebijakan dakwah sebagai salah satu solusi untuk mengatasi probem degradasi moral remaja

Di era reformasi saat ini, pemerintah atau negara memberikan ruang dan akomodasi secara luas kepada setiap kelompok untuk berorganisasi dan berpendapat. Pada era otonomi desa, setiap desa memiliki otoritas dalam batas tertentu untuk mengurus wilayahnya sesuai dengan kehendak masyarakatnya. Peluang tersebut yang dijadikan oleh Pemerintah Desa untuk membuat kebijakan publik yang bernuansa islami dalam bentuk Peraturan Desa yang mengacu pada syariat Islam.

Setiap masyarakat memiliki budaya tertentu yang membedakan nilai-nilai dan gaya hidup anggota-anggotanya dari anggota masyarakat yang lain. Secara umum, budaya masyarakat dapat disebut sebagai budaya politik yang menyangkut tingkah laku, nilai-nilai, dan kepercayaan yang dijadikan pegangan secara luas tentang apa yang semestinya dilakukan oleh pemerintah dan bagaimana pemerintah harus melaksanakan tugas dan tanggung jawabnya.

Kebijakan dakwah yang diwujudkan melalui kebijakan publik di Desa Margoyoso Kalinyamatan Jepara tergantung pada politik pihak Kepala Desa dalam menentukan karakteristik dan coraknya. Pada era kepemimpinan sebelum Miftakhul Huda, belum pernah ada kebijakan publik keagamaan yang dibentuk oleh Pemerintah Desa. Upaya menjadikan Desa Margoyoso sebagai desa yang religius sudah direncanakan oleh Kepala Desa saat ini ketika masa kampanye pemilihan Kepala Desa pada tahun 2016. Pada saat kampanye, janji untuk menjadikan Margoyoso sebagai desa yang religius disampaikan dalam berbagai kesempatan. Selain itu, janji tersebut juga disebarkan melalui berbagai macam alat praga kampanye seperti baner, pamflet, dan lain sebagainya. 
Lahirnya kebijakan dakwah di Desa Margoyoso dipengaruhi oleh berbagai aspek seperti aspek sejarah, aspek politik lokal, dan aspek gerakan sosial keagamaan. Aspek sejarah berkaitan dengan bagaimana karakter desa Margoyoso yang sejah dahulu terkenal dengan tingkat religiusitasnya. Desa Margoyoso dikenal sebagai Desa yang memiliki nuansa keagamaan kuat, selain itu, di Margoyoso juga terdapat banyak tokoh agama yang memiliki pengaruh kuat.

Aspek politik berkaitan dengan perebutan kekuasaan di tingkat desa. Bagi seorang politisi atau incumbent yang ingin mencalonkan diri menjadi kepala desa, adanya kebijakan keagamaan sebagai bagian dari visi misi dapat dijadikan sebagai alat untuk meraih simpati publik. Sebagaimana yang dilakukan oleh Kepala Desa saat ini yang berjanji akan menjadikan Margoyoso sebagai desa yang agamis dalam kampanye pemilihan petinggi dahulu. Adapun aspek sosial keagamaan berkaitan dengan adanya kelompok keagamaan yang memiliki pengaruh kuat di Margoyoso, yaitu Nahdlatul Ulama.

Dakwah yang dikemas melalui model kebijakan publik di Desa Margoyoso diputuskan setelah melalui berbagai tahapan. Pada tahap penyusunan agenda kebijakan, terdapat ada tiga hal yang dilakukan oleh pemerintah Desa Margoyoso. Pertama, membangun persepsi di kalangan stakeholders bahwa sebuah fenomena benar-benar dianggap sebagai masalah yang serius, sebab boleh jadi suatu gejala atau fenomena di kelompok masyarakat dianggap masalah, tetapi oleh sebagian masyarakat yang lain atau elit politik bukan dianggap sebagai masalah. Kedua, membuat batasan dari permasalahan agar dapat terarah secara jelas. Ketiga, menggerakkan dukungan agar permasalahan tersebut dapat masuk dalam agenda pemerintah. Mobilisasi dukungan dapat dilakukan dengan berbagai cara seperti mengorganisir kelompok-kelompok yang ada dalam masyarakat, melalui kekuatan politik, publikasi melalui media, dan lain sebagainya.

Jika melihat cara isu menjadi sebuah agenda kebijakan dakwah Pemerintah Desa Margoyoso karena ada inisiatif dari pihak pemerintah, yaitu Sudi Hariyanto selaku Kaur. Perencanaan yang kemudian didukung oleh kepala desa, perangkat desa, dan pihak luar pemerintah, baik dari perorangan maupun kelompok keagamaan seperti Nahdlatul Ulama Ranting Margoyoso. Penerapan kebijakan dakwah tersebut sarat dengan kepentingan politik Pemerintah Desa. Margoyoso 
yang mayoritas penduduknya beragama Islam dan berafiliasi pada kelompok keagamaan Nahdlatul Ulama menjadikan Kepala Desa mengkampanyekan penegakan dakwah melalui kebijakan publik. Hal tersebut membuka peluang untuk saling mempengaruhi antara politisi yang ingin mendapatkan dukungan masyarakat dalam pemilihan kepala desa berikutnya.

Meskipun demikian, menurut Miftakhul Huda, Kepala Desa Margoyoso, kebijakan dakwah tersebut merupakan kebutuhan masyarakat yang mayoritas beragama Islam. Proses pembuatan kebijakan dakwah telah dirumuskan oleh pemerintah desa bersama dengan Badan Perwakilan Desa, tokoh masyarakat, dan tokoh agama setempat.

Pemerintah Desa Margoyoso menggunakan strategi audiensi sebagai langkah awal perumusan kebijakan keagamaan. Pemerintah Desa mengundang para tokoh agama, tokoh masyarakat, BPD, nadhir, pimpinan lembaga pendidikan dan keagamaan, serta stake holder terkait untuk ikut serta dalam diskusi tentang rencana strategis kebijakan keagamaan yang dikonsep oleh Pemerintah Desa. Model audiensi yang digunakan oleh Pemerintah Desa cukup efektif menjadi strategi komunikasi dalam perumusan kebijakan. Pemerintah Desa hanya memerlukan sekali audiensi agar rencana kebijakan strategis tersebut dapat diterima oleh warga dan pihak terkait. Tidak adanya penolakan atau pertentangan dalam proses audiensi juga dilatarbelakangi oleh faktor kekuatan pemerintah yang didominasi oleh mayoritas tokoh strategis dan menjadi panutan di masing-masing dukuh.

\section{Sosialisasi Kebijakan Dakwah}

Sosialisasi merupakan bagaimana Pemerintah Desa mengkomunikasikan kebijakan keagamaan kepada warga masyarakat Margoyoso. Proses komunikasi dari program kebijakan dakwah tentu penting untuk diperhatikan agar warga masyarakat sebagai sasaran dakwah dapat menerima, memahami, dan ikut serta dalam program kebijakan yang telah ditetapkan. ${ }^{11}$ Keberhasilan dari proses komunikasi tersebut dipengaruhi oleh beberapa hal seperti pihak-pihak yang terlibat dalam komunikasi atau komunikator, cara yang ditempuh, kepentingan atau tujuan

\footnotetext{
${ }^{11}$ Sumadi Dilla, Komunikasi Pembangunan, (Bandung: Simbiosa Rekatama Media, 2007), hlm. 116
} 
komunikasi, ruang lingkup, saluran atau media yang digunakan, dan isi pesan yang disampaikan. ${ }^{12}$

Komunikasi dalam sosialisasi kebijakan dakwah di pemerintahan desa Margoyoso selama ini dilakukan dengan berbagai macam pendekatan seperti struktural, kultural, majlis taklim, media sosial, dan lain sebagainya. Pendekatan struktural merupakan proses komunikasi program keagamaan dilaksanakan oleh pemerintah desa secara legal formal dengan mengundang para tokoh agama, tokoh masyarakat, nadhir masjid dan mushola, serta stake holder terkait di Balai Desa Margoyoso. Pendekatan ini juga sebagai tindak lanjut dari kegiatan audiensi perumusan kebijakan yang telah dilaksanakan. Melalui pendekatan struktural, Pemerintah Desa memiliki harapan agar para tokoh dan stake holder terkait tersebut mampu mengkomunikasikan dan menginformasikan program kebijakan desa kepada warga sehingga dapat diterima dengan baik. Pendekatan kultural selama ini dilakukan oleh para stakeholder terkait melalui informasi secara langsung kepada sasaran program seperti melalui forum pengajian umum, pengajian ibu-ibu, majlis ta'lim, kegiatan diniyah, dan lain sebagainya. Pendekatan kultural yang dilakukan oleh Pemerintah Desa memiliki sasaran utama golongan ibu ibu atau perempuan. Hal tersebut dimaksudkan agar program tersebut mampu diinformasikan kembali di lingkup lingkungankeluarga. Sosialisasi juga dilakukan oleh Pemerintah Desa melalui sosial media, Facebook. Pemerintah Desa juga membuat berbagai macam pamflet yang ditempel di berbagai masjid, mushola, dan jalan raya.

\section{Implementasi Kebijakan Dakwah}

Pemerintah Desa Margoyoso bersama Badan Perwakilan Desa (BPD), dan berdasarkan saran dan masukan dari berbagai tokoh masyarakat dan tokoh agama Margoyoso merumuskan dan menetapkan beberapa kebijakan dakwah kolaboratif yang meliputi shalat subuh berjamaah, mematikan televisi setelah maghrib, ayo mengaji, dan wajib madrasah diniyah. Kebijakan tersebut sampai saat ini belum memiliki kekuatan hukum tetap dan mengikat, artinya produk kebijakan tersebut selama ini berjalan dengan model dakwah atau anjuran dalam rangka menngkatkan keimanan dan religiusitas masyarakat desa yang disertai dengan kontrol dan 
keteladanan dari pemerintah desa. Kebijakan dakwah kolaboratif di desa Margoyoso yang dibuat oleh Pemerintah Desa hanya bersifat mendorong, memotivasi, dan mengajak masyarakat untuk menjalankan ajaran agama Islam dengan baik. Munculnya kebijakan tersebut tidak memiliki tujuan untuk menjadikan Margoyoso menjadi desa syariah, serta tidak ada niat dan tujuan yang mengarah pada upaya menciptakan konstitusi berbasis Syariah.

Kebijakan shalat subuh berjamaah dilakukan pemerintah desa Margoyoso pada setiap hari sabtu dengan teknis idaroh atau bergantian di setiap masjid atau mushola. Di Margoyoso terdapat 20 masjid atau mushola yang tersebar secara merata. Kebijakan shalat subuh berjamaah dikoordinir oleh perangkat desa bagian pelayanan atau moden, yaitu Maftukhin Lutfi dan Samsudin. Sebelum pelaksanaan kebijakan, tepatnya pada tahap perumusan kebijakan, Pemerintah Desa mengumpulkan para takmir masjid dan mushola untuk berdiskusi dan merespon beberapa wacana kebijakan dakwah yang akan dilaksanakan oleh pemerintah desa.

Teknis pelaksanaannya adalah dengan melakukan sosialisasi terlebih dahulu kepada para takmir masjid dan mushola di Balai Desa. Upaya sosialisasi juga dilakukan dengan membuat pamflet dan brosur yang dipasang di tempattempat strategis seperti perempatan jalan, pos ronda, tempat keramaian, dan masjid atau mushola. Mayoritas perangkat desa yang sekaligus menjadi tokoh organisasi sosial keagamaan juga menjadi kelebihan tersendiri dalam proses sosialisasi kebijakan ini. Kegiatan safari subuh dilakukan oleh Pemerintah Desa Margoyoso di 21 tempat ibadah yang terdiri dari masjid dan mushola yang ada di lingkungan masyarakat Margoyoso secara rutin pada sabtu subuh. Kegiatan tersebut menarik, karena kepala desa mengintruksikan kepada seluruh perangkat desa agar memberikan keteladanan dengan wajib hadir di acara tersebut.

Sebelum kegiatan dilaksanakan, koordinator atau penanggung jawab memberikan surat pemberitahuan kepada nadhir atau takmir yang mendapatkan giliran tempat setiap hari senin dengan disertai pemberian uang sumbangan lima ratus ribu rupiah untuk biaya konsumsi. Uang tersebut diambilkan dari anggaran dana desa (ADD) dan CSR dari Bank BRI dan BNI. Untuk semakin menguatkan sosialisasi pelaksanaan program, setiap hari jumat juga digunakan untuk sosialisasi kepada warga masyarakat tentang tempat pelaksanaan safari subuh saat itu. 
Koordinator memanfaatkan momentum salat jumat sebagai media untuk sosalisasi dengan memberikan pengumuman sebelum pelaksanaan khutbah dimulai.

Kebijakan mematikan televisi setelah maghrib merupakan salah satu kebijakan dakwah Pemerintah Desa Margoyoso yang bertujuan untuk membentuk karakter, kepribadian, dan membentengi remaja dari pengaruh televisi yang menyebabkan terjadinya degradasi moral. Implementasi kebijakan mematikan televisi setelah maghrib dikoordinir oleh Kasi Pelayanan atau moden desa, yaitu Maftukhin Lutfi dan Samsudin. Kordinator tersebut menjalin kerja sama dengan tokoh agama, tokoh masyarakat, RT, dan koordinator wilayah untuk ikut serta dalam suksesi pelaksanaan melalui pemberian pengertian dan pengarahan, serta pengawsasan. Sejauh ini, belum ada sanksi yang jelas yang diberikan kepada warga masyarakat Margoyoso yang tidak menjalankan intruksi tersebut. Pihak Pemerintah Desa hanya bersifat mengajak, mendorong dan memberikan sanksi sosial berupa teguran melalui koordinator wilayah.

Kebijakan mengaji al quran setelah maghrib merupakan kebijakan dakwah yang sepaket dengan kebijakan mematikan televisi setelah maghrib. Setelah masyarakat mematikan televisi setelah maghrib, Pihak Pemerintah Desa berharap agar masyarakat menjalankan aktifitas keagamaan berupa mengaji alquran. Koordinator dari pelaksanaan kebijakan ini adalah Maftukhin Lutfi dan Samsudin selaku Kasi Pelayanan dan moden Margoyoso. Koordinator kebijakan selanjutnya berkoordinasi dengan para tokoh agama, guru, ustaz, lingkungan keluarga, dan koordinator wilayah untuk mendorong para remaja agar ikut serta menjalankan kegiatan ini.

Menurut Maftukhin, Sasaran kebijakan ini sebenarnya ditujukan tidak hanya kepada para remaja saja, tetapi juga kepada lingkungan keluarga, karena lingkungan tersebut sangat berpengaruh terhadap kesediaan anaknya dalam mengaji. Jika orang tua atau lingkungan keluarga ikut mengajak dan mendorong dengan memberikan keteladanan, maka anaknya juga akan lebih mudah untuk ikut serta dalam mengaji tersebut. Untuk memberikan apresiasi kepada ustaz dan tokoh agama yang berkenan mengajar anak mengaji, Pemerintah Desa Margoyoso selama ini memberikan bantuan insentif yang dicairkan setahun sekali ketika bulan ramadhan. 
Di Margoyoso, pendirian madrasah diniyah memiliki latar belakang yang unik, dimana kebanyakan didirikan oleh perorangan yang semata-mata bertujuan untuk ibadah. Sistem yang diguanakan adalah tergantung kepada latar belakang pendiri dan pengasuhnya sehinga pertumbuhan madrasah diniyah memiliki banyak ragam dan coraknya. Pendidikan madrasah diniyah memiliki dua sistem pembelajaran, yaitu sistem sekolah dan non sekolah. Pada sistem sekolah, madrasah diniyah menggunakan konsep kelas dalam pelaksanannya, yaitu kelas 1 sampai dengan kelas VI disebut diniyah ula, kelas VII sampai IX disebut diniyah wustho, dan kelas X sampai XII disebut diniyah ulya. Pendidikan diniyah secara khusus hanya mempelajari ilmu agama dan bahasa Arab. Potensi yang ada di madrasah diniyah tidak jauh berbeda dengan potensi pondok pesantren, karena keduanya terbentuk, lahir, tumbuh dan berkembang di tengah masyarakat dan dilatarbelakangi oleh kebutuhan masyarakat.

Kekuatan utama madrasah diniyah adalah kemampuannya menghadapi berbagai masalah yang muncul. Meskipun dengan kondisi yang serba kekurangan, Madrasah diniyah justru semakin berkembang. Pola, pendekatan, dan sistem pembelajarannya juga tidak terikat dengan modelmodel tertentu. Kebijakan yang diterapkan di Margoyoso adalah minimal sampai batas diniyah ula atau kelas I sampai VI, sehingga yang menjadi sasaran program kebijakan dakwah Pemerintah Desa pada umumnya adalah anak-anak dan remaja. Menurut Maftuhin, kegiatan madrasah diniyah di Margoyoso selama ini diikuti oleh anak-anak yang tidak hanya dari latar belakang Nahdlatul Ulama, tetapi juga dari Muhammadiyah. Namun, mengacu pada data desa, dimana anak-anak usia 5-14 tahun yang menjadi sasaran kebijakan wajib madrasah diniyah jumlahnya mencapai 1310 anak. Angka tersebut tentu sangat besar sehingga memerlukan perhatian, penanganan, dan pembinaan yang serius. Melihat data madrasah diniyah yang saat ini ada di Margoyoso berjumlah 3 lembaga perlu menjadi pertimbangan Pemerintah dalam proses implementasi kebijakan tersebut. Jangan sampai adanya kebijakan wajib madrasah diniyah justru menjadi permasalahan baru jika tidak mendapatkan pembinaan dan perhatian yang serius dari Pemerintah Desa. 


\section{Monitoring dan Evaluasi Dakwah}

Monitoring merupakan hal penting yang harus diterapkan dalam konsep manajemen dakwah, yang dalam hal ini adalah terhadap dakwah struktural yang dilakukan oleh Pemerintah Desa Margoyoso melalui kebijakan publik. Monitoring diperlukan oleh Pemerintah Desa Margoyoso untuk mengetahui bagaimana kinerja dari kebijakan dakwah, untuk memastikan langkah kemajuan yang telah dicapai dari aktifitas dakwah, untuk mengantisipasi agar kesalahankesalahan awal sehingga dapat dilakukan perbaikan untuk mengurangi resiko yang lebih besar, dan sebagai upaya untuk memonitor keefektifan aktifitas dakwah yang meliputi perencanaan, pengorganisasian, dan kepemimpinan.

Kebijakan salat subuh berjamaah, mematikan televisi setelah maghrib, ayo mengaji, dan wajib madrasah diniyah, tugas monitoring diberikan kepada koordinator dan penanggung jawab program yaitu Maftukhin Lutfi dan Syamsudin yang dalam struktural Pemerintah Desa menjabat sebagai Kasi dan Staf Pelayanan atau moden. Jabatan struktural tersebut sangat strategis, karena merupakan posisi yang menjadi teladan atau pemimpin dalam bidang kemasyarakatan dan kegamaan di lingkungan pemerintahan Desa Margoyoso.

Program salat subuh berjamaah yang dilakukan setiap sabtu subuh di masjid atau mushola menjadi program unggulan desa dan selama ini berjalan dengan rutin. Upaya monitoring untuk mengetahui berjalannya program dilakukan dengan mengikuti program tersebut. Pemerintah Desa juga mewajibkan seluruh perangkat desa untuk ikut serta dalam safari subuh berjamaah. Menurut hukum agama, kegiatan salat jamaah memiliki hukum sunnah muakkad atau sangat dianjurkan. Atas pertimbangan hukum tersebut, Pemerintah Desa Margoyoso tidak mewajibkan, namun hanya mendorong, dan sangat menganjurkan dengan cara dituangkan melalui kebijakan publik.

Program mematikan televisi setelah maghrib yang dikombinasikan dengan gerakan ayo mengaji merupakan program inovasi baru dari pemerintah Desa Margoyoso sebagai upaya menaggulangi perkembangan teknologi informasi yang sangat cepat dan berbagai macam bentuk degradasi moral. Selain itu, program tersebut juga untuk mengembalikan tradisi masa lalu dimana waktu setelah maghrib menjadi waktu yang istimewa dan diisi melalui kegiatan mengaji alquran 
Setelah melakukan monitoring, langkah penting yang lain untuk mensukseskan aktifitas dakwah adalah evaluasi. Evaluasi dilakukan oleh Pemerintah Desa Margoyoso untuk meningkatkan manajerial dakwah dalam sebuah program yang dapat mendorong koordinator atau penanggung jawab dakwah untuk mengamati perilaku anggotanya melalui pengamatan yang lebih mendalam yang didapatkan melalui saling pengertian di antara kedua belah pihak. Evaluasi dakwah tersebut memiliki tujuan untuk memberikan penilaian tentang berjalannya kegiatan dakwah. Selain itu, evaluasi juga memiliki tujuan untuk mencapai kesimpulan dakwah yang evaluatif dan untuk memberikan pertimbangan dan perkembangan dari aktifitas dakwah. ${ }^{13}$

Kriteria yang diterapkan oleh Pemerintah Desa Margoyoso dalam evaluasi adalah seluruh proses evaluasi yang sudah disusun secara objektif. Evaluasi dilakukan sedapat mungkin berhubungan dengan bidang keahlian yang bersangkutan sehingga dapat menghasilkan sebuah analisis pekerjaan yang mendalam. Dalam kegiatan dakwah, evaluasi perlu diterapkan dalam setiap tahap, baik tahap perencanaan maupun tahap pelaksanaan.

Kegiatan monitoring memerlukan data dan informasi sebagai bahan untuk melakukan penilaian terhadap proses implementasi kebijakan. Dalam program salat subuh berjamaah di Desa Margoyoso, metode yang diterapkan untuk proses monitoring dan evaluasi adalah pertama, dokumentasi. Yaitu melalui laporan kegiatan berupa foto dan laporan berjalannya kegiatan tersebut. Kedua, observasi lapangan. Metode ini dilakukan setiap pelaksanaan kegiatan. Koordinator atau penanggung jawab mengamati proses berjalannya kegiatan dan membandingkan ketika dihadiri pemerintah desa dan tidak memiliki jumlah jamaah yang sama atau tidak. Hal tersebut untuk mengukur bagaimana motivasi dan hasil keteladanan yang telah diberikan oleh segenap pemerintah Desa. Ketiga, Fokus Group Discusion, yaitu dilaksanakan setelah acara ramah tamah atau seremonial dengan membaur bersama warga. Biasanya dilaksanakan dengan makan bersama sehingga mendapatkan hasil data yang jelas dan apa adanya. Keempat, wawancara dengan

${ }^{13}$ Secara khusus, tujuan dari adanya evaluasi adalah untuk mengidentifikasi sumber daya da'I yang potensial, untuk menentukan kebutuhan pelatihan dan pengembangan bagi individu dan kelompok dalam sebuah lembaga atau organisasi, dan untuk mengidentifikasi para anggota yang akan dipromosikan dalam penempatan posisi tertentu. M. Munir dan Wahyu Ilaihi, Manajemen Dakwah, 183-184. 
stakeholder. Langkah ini dilakukan melalui koordinasi dengan tokoh agama dan tokoh masyarakat setempat. Kegiatan ini biasanya dilakukan per tiga bulan sekaligus untuk mengevaluasi bagaimana perkembangan perjalanan kebijakan dakwah tersebut.

Perjalanan kebijakan dakwah di Desa Margoyoso tidak terlepas dari adanya faktor pendukung dan faktor penghambat yang mengiringinya. Faktor pendukung merupakan faktor kekuatan yang dapat membantu kebijakan tersebut dapat berjalan dengan lancar. Sedangkan faktor penghambat merupakan faktor kelemahan yang menghambat kelancaran dan berjalannya implementasi kebijakan dakwah. Dari keempat kebijakan dakwah yang telah ditetapkan dan diimplementasikan oleh Pemerintah Desa, terdapat faktor pendukung dan penghambat masing-masing.

Secara umum, faktor pendukung dari kebijakan dakwah adalah kondisi masyarakat desa yang seluruhnya adalah beragama Islam sehingga tidak ada pertentangan dari adanya kebijakan dakwah yang dibuat dan ditetapkan oleh Pemerintah Desa tersebut. Selain itu, yang menjadi faktor pendukung lainnya adalah banyaknya perangkat desa yang ikut serta aktif di organisasi sosial keagamaan dengan menempati posisi strategis. Misalnya Mafukhin Lutfi, selain menjadi kasi pelayanan atau moden dan koordinator kebijakan keagamaan. juga menjadi Rais Syuriyah Pimpinan Ranting Nahdlatul Ulama Desa Margoyoso. Posisi tersebut sangat strategis, karena menjadi orang pertama secara struktural yang dijadikan rujukan oleh warga nahdliyin yang merupakan organisasi mayoritas di Desa Margoyoso.

Faktor pendukung lainnya, ada juga perangkat desa yang menjadi ketua Fatayat Nahdlatul Ulama Ranting Margoyoso. Fatayat merupakan organisasi sosial keagamaan dan kemasyarakatan di bawah naungan Nahdlatul Ulama yang menaungi kaum perempuan dewasa. Tentu hal tersebut memudahkan bagi pemerintah desa untuk mensosialisasikan dan membantu implementasi kebijakan dakwah dengan baik. Perangkat desa yang lainnya juga ada yang menjadi tokoh agama di lingkungan rumahnya masing-masing sehingga memiliki penggaruh dan kekuatan tersendiri dalam mengajak masyarakatnya untuk menjalankan kebijakan dakwah tersebut. 
Faktor penghambat dari kebijakan dakwah ini adalah belum matangnya konsep manajemen dakwah sehingga berpengaruh terhadap kelancaran dan kesuksesan dakwah. Faktor penghambat terbesar dari kebijakan dakwah tersebut adalah isi kebijakan dakwah yang merupakan masalah privat sehingga menjadikan program kebijakan dakwah terhambat kelancarannya. Selain itu, dari unsur internal Pemerintah Desa juga masih ada beberapa yang belum konsisten untuk ikut serta dalam implementasi kebijakan dakwah, terutama yang berkaitan dengan kebijakan mematikan televisi setelah maghrib yang diikuti dengan gerakan ayo mengaji alquran.

\section{Manfaat Kebijakan Dakwah Kolaboratif}

Manfaat adanya kebijakan dakwah diklasifikasikan menjadi tiga bagian, yaitu jangka pendek, jangka menengah, dan jangka panjang. Manfaat dari kebijakan yang telah ditetapkan oleh Pemerintah Desa Margoyoso adalah sebagai upaya membangun desa yang religius dan menanggulangi berbagai macam problematika masyarakat dispesifikasikan menjadi beberapa hal. Pertama, Membangun kedekatan emosional antara pemerintah dengan warga. Program safari salat subuh berjamaah yang dilakukan oleh Pemerintah Desa sebagai upaya memberikan keteladanan dan ajakan kepada warga mampu menjadi wadah silaturrahmi antara Pemerintah Desa dengan warga Masyarakat. Program tersebut dilakukan setiap sabtu subuh secara keliling di setiap masjid atau mushola sesuai jadwal yang telah ditentukan.

Program safari subuh berjamaah diikuti oleh semua pejabat Pemerintah Desa dari unsur eksekutif dengan konsep idaroh. Setelah menjalankan shalat subuh kemudian dikemas dengan acara diskusi, pengajian, dan ramah tamah atau makan bersama. Acara tersebut dihadiri oleh segenap warga di lingkungan sekitar masjid atau mushola yang mendapatkan giliran tuan rumah dan juga dihadiri oleh para tokoh agama dan tokoh masyarakat di lingkungan desa Margoyoso. Safari subuh selain sebagai upaya monitoring, dan dorongan untuk menjalankan shalat subuh secara berjamaah, juga dapat menjadi media membangun citra pemerintah yang merakyat dan menjauhkan dari image elitis. Selama ini Pemerintah Desa dicitrakan elitis yang menjaga jarak dengan warga masyarakat. Sebelum Pemerintahan era Miftakhul Huda terjadi gap atau jarak antara warga dengan Pemerintah Desa 
Kedua, Media sosialisasi program dan informasi desa. Kegiatan safari subuh berjamaah yang dilanjutkan dengan forum diskusi, pengajian, dan makan bersama, dimanfaatkan oleh Pemerintah Desa untuk menyampaikan berbagai macam program dan informasi tentang desa kepada warga masyarakat. Sebelum adanya kegiatan ini, Pemerintah Desa hanya menyampaikan program dan informasi desa melalui cara mengumpulkan RT dan RW di balai desa dan memberikan surat edaran.

Semua unsur eksekutif Pemerintah Desa dapat bertatap muka secara langsung dengan warganya. Selain untuk membangun kedekatan, menjalin keakraban, dan silaturrahmi dengan warga masyarakat, Pemerintah Desa juga dapat mengetahui respon secara langsung dari warga masyarakat atas berbagai macam program dan informasi desa melalui forum diskusi. Diskusi dan penyampaian program serta informasi desa biasanya dipimpin oleh Kepala Desa, Miftakhul Huda bersama Sekretaris Desa, Solihin. Adanya kegiatan ini juga mendapatkan respon yang positif dari warga masyarakat Maroyoso.

Dengan adanya safari subuh ini, Pemerintah Desa ingin agar hubungan antara Pemerintah Desa dan warga semakin akrab, kalau ada program dan informasi dari desa segera tersampaikan secara langsung kepada masyarakat. Kalau biasanya pemerintah menyampaikan secara langsung, nanti ada respon dan tanggapan dari warga sehingga hal tersebut akan lebih mudah dijalankan bersama-sama. Contohnya kalau ada program dan informasi tentang program kebersihan desa seperti bank sampah, kemudian ada rencana mobil ambulance desa, itu kami sampaikan juga di forum safari subuh ini.

Ketiga, Media peningkatan kualitas pendidikan dan keagamaan. Lahirnya kebijakan salat subuh berjamaah, mematikan televisi yang diikuti dengan ayo mengaji, dan kebijakan wajib masrasah diniyah menjadi kebijakan yang diharapkan oleh Pemerintah Desa dapat menjadi media untuk menigkatkan kualitas pendidikan dan keagamaan warga masyarakat. Desa berharap agar semua anak-anak dan remaja mampu membaca alquran dan mengerti ilmuilmu agama. Pendidikan agama memiliki posisi dan peran yang strategis dalam membangun karakter bangsa. Madrasah sebagai lembaga pendidikan Islam yang bersifat kerakyatan, perannya dalam proses internalisasi ajaran-ajaran Islam dan tradisi keagamaan menjadi 
sangat penting. Madrasah diniyah memiliki signifikansi dalam melestarikan keberlangsungan pendidikan Islam dan nilai moral keislaman bagi masyarakat.

Kebijakan dakwah juga dibuat oleh Pemerintah Desa untuk mengatasi permasalahan sosial masyarakat. Seiring perkembangan teknologi informasi, dan era globalisasi yang begitu cepat sehingga memiliki berbagai macam efek, termasuk efek negatif yang ditandai dengan adanya degradasi moral, kenakalan remaja, dan lain sebagainya. Madrasah Diniyah dijadikan Pemerintah Desa Margoyso sebagai lembaga yang diharapkan mampu mencetak generasi yang memiliki akhlak dan budi pekerti luhur, mampu membaca alquran, mengerti dan faham ilmu agama, serta membentengi generasi muda dari pengaruh negatif kemajuan zaman tersebut melalui kebijakan wajib madrasah diniyah.

\section{KESIMPULAN}

Komunikasi dakwah yang dilakukan oleh Pemerintah Desa Margoyoso dalam membangun desa yang religius dipengaruhi dengan adanya regulasi otonomi desa, dimana Pemerintah Desa dapat mengelola dan mengatur daerah atau wilayah pemerintahannya sesuai dengan khas dan coraknya masing-masing. Munculnya kebijakan dakwah di Desa Margoyoso tidak dapat dipisahkan dengan dua hal, yaitu permasalahan sosial berupa degradasi moral dan kebijakan politik keagamaan dari Pemerintah Desa.

Implementasi kebijakan dakwah kolaboratif tersebut sarat dengan berbagai kepentingan politik dari Pemerintah Desa Margoyoso yang penduduknya mayoritas beragama Islam. Kebijakan dakwah tersebut juga dipengaruhi oleh berbagai aspek seperti aspek politik lokal dan aspek gerakan sosial keagamaan. Aspek politik memiliki keterkaitan dengan posisi strategis kekuasaan di tingkat desa. Sedangkan aspek sosial keagamaan memiliki keterkaitan dengan adanya organisasi sosial keagamaan yang memiliki pengaruh kuat di Desa Margoyoso, yaitu Nahdlatul Ulama.

Komunikasi dakwah melalui kebijakan publik dilakukan melalui beberapa tahap seperti formulasi masalah, perumusan kebijakan, perencanaan program pelaksanaan dan proses legitimasi dan komunikasi. Pemerintah Desa Margoyoso merumuskan kebijakan tersebut bersama Badan Perwakilan Desa, tokoh agama, 
dan tokoh masyarakat. Isi kebijakan tersebut meliputi shalat subuh berjamaah, mematikan televisi setelah maghrib, ayo mengaji, dan wajib madrasah diniyah.

Komunikasi dalam sosialisasi kebijakan dakwah di pemerintahan desa Margoyoso selama ini dilakukan dengan berbagai macam pendekatan seperti struktural, kultural, majlis taklim, media sosial, dan lain sebagainya. Pendekatan struktural dilaksanakan oleh pemerintah desa secara legal formal dengan mengundang para tokoh agama, tokoh masyarakat, nadhir masjid dan mushola, serta stake holder terkait di Balai Desa Margoyoso. Pendekatan kultural selama ini dilakukan oleh para stakeholder terkait melalui informasi secara langsung kepada sasaran program seperti melalui forum pengajian umum, pengajian ibu-ibu, majlis ta'lim, kegiatan diniyah, dan lain sebagainya. Sosialisasi juga dilakukan oleh Pemerintah Desa melalui sosial media, Facebook. Pemerintah Desa juga membuat berbagai macam pamflet yang ditempel di berbagai masjid, mushola, dan jalan raya.

\section{DAFTAR PUSTAKA}

Abidin, Said Zainal. Kebijakan Publik, Jakarta: Salemba Humanika, 2012.

Al Faruqi, Ismail R. Menjelajah Atlas Dunia Islam, Bandung: Mizan, 2000.

Amin, Samsul Munir. Ilmu Dakwah, Jakarta: Amzah, 2009.

Anshari, Hafi. Pemahaman dan Pengalaman Dakwah, Surabaya: Al Ikhlas, 1993.

Basit, Abdul. Filsafat Dakwah. Jakarta: PT Raja Grafindo Persada, 2013.

Dye, Thomas. R. Understanding Public Policy, America: Pearson, 2013.

Kayo, Khatib Pahlawan. Manajemen Dakwah, Jakarta: Amzah, 2007.

Lexy J Moleong, Metodologi Penelitian Kualitatif, Bandung: PT. Remaja Rosdakarya, 2016.

Maryolo, Amril. "Formalisasi Syariat Islam di Bulukumba", Tesis Program Studi Islamic Interdisciplinary Studies UIN Sunan Kalijaga Yogyakarta, 2017.

Muqsi. Hubungan Dakwah dan Komunikasi, Jurnal Peurawi: Media Kajian Komunikasi Islam, Vol. 1 No. 1. 2018.

Nugroho, Riant. Public Policy, Jakarta: Elex Media Komputindo, 2017.

Purwanto, Erwan Agus dkk. Mengembangkan Profesi Analisis Kebijakan, Yogyakarta: Gadjah Mada University Press, 2015.

Santoso, Purwo. Modul Pembelajaran Analisis Kebijakan Publik, Yogyakarta: PolGov, 2010. 
Schneider, Anne Policy Design and Transfer, Eduardo Araral, dkk (ed), Routledge Handbook of Public Policy, Newyork: Routledge, 2013.

Subarsono. Analisis Kebijakan Publik. Yogyakarta: Pustaka Pelajar, 2008.

Sukayat, Tata. Ilmu Dakwah. Bandung: Simbiosa Rekatama Media, 2015.

Winarno, Budi. Kebijakan Publik: Teori dan Proses, Yogyakarta: Medpress, 2008. 